KS. LUCJAN ŚWITO

Uniwersytet Warmińsko Mazurski w Olsztynie

\title{
REKWIZYCJA CYWILNO-KANONICZNA? POMOC SĄDOWA POMIĘDZY TRYBUNALAMI KOŚCIELNYMI A SĄDOWNICTWEM POWSZECHNYM W POLSCE
}

Treść: Wstęp. - 1. Istota rekwizycji. - 2. Współpraca sądów kościelnych z sądami powszechnymi w przedmiocie rekwizycji - analiza prawna. - 2.1. Dopuszczalność pozyskiwania dowodu w kanonicznym procesie małżeńskim za pośrednictwem sądu powszechnego. -2.2 . Dopuszczalność wykonania przez sąd powszechny pomocy sądowej z wniosku sądu kościelnego. - 2.3. Rekwizycja z wniosku sądu powszechnego? -3. Wykonanie odezwy trybunału kościelnego - uwagi praktyczne. - Zakończenie.

\section{Wstęp}

Przemiany ustrojowo-polityczne w Polsce końca XX wieku wpłynęły zarówno na zmiany strukturalne społeczeństwa, jak i na zmianę prawa oraz społecznych oczekiwań wobec niego. Otwarcie na świat, ekspansja prądów myślowych podkreślających prawa człowieka znalazły swoje przełożenie nie tylko w licznych zmianach obowiązujących regulacji prawnych, ale poczyniły również, dający się wyraźnie dostrzec, wyłom w społecznym odbiorze prawa, a zwłaszcza w ocenie jego roli. Obywatel w zetknięciu z prawem przestał czuć się jego „przedmiotem”, stając się świadomym i coraz bardziej aktywnym uczestnikiem postępowania. Strony nie tylko coraz bardziej świadome są swych praw i coraz skuteczniej potrafią egzekwować je w procesie, ale również coraz szerzej korzystają z pomocy podmiotów kwalifikowanych, jak adwokaci czy radcowie prawni. Coraz częściej też inicjatywa dowodowa stron i podmiotów ich reprezentujących wykracza poza obszar kraju i prawo rodzime, zaś pomoc prawna pomiędzy 
sądami polskimi i zagranicznymi - wykonywana przez sądy również w ramach tzw. działań podejmowanych z urzędu - stanowi coraz prężniej rozwijającą się płaszczyznę sądowej aktywności.

Wzrost świadomości prawnej oraz zmiana społecznej mentalności w relacji wobec prawa nie jest zjawiskiem właściwym wyłącznie współczesnemu sądownictwu świeckiemu. Tendencję tę dostrzec można również w kanonicznych procesach małżeńskich, o czym świadczy zarówno samo zwiększenie liczby spraw ${ }^{1}$, jak i wymowa zgłaszanych przez strony i ich pełnomocników wniosków. Fakt ten trudno uznać za zdumiewający, skoro kanoniczny proces o stwierdzenie nieważności małżeństwa dotyczy wiernych żyjących w świecie w podlegającej przemianom rzeczywistości społeczno-prawnej. Ponadto proces ten zazwyczaj poprzedzony jest postępowaniem rozwodowym i strony wnoszące skargę do trybunału kościelnego mają z reguły już za sobą procesowe doświadczenia. Często wielorakie i bardzo trudne, dotyczące nie tylko kwestii małżeństwa, ale i ustalenia kontaktów z dziećmi, czy spraw związanych z podziałem majątku, co nierzadko wzmaga determinację i rzutuje na postawę stron również w procesie kościelnym. Wszystko to sprawia, iż w kanonicznym procesie o stwierdzenie nieważności małżeństwa coraz częściej można spotkać inicjatywę dowodową stron i ich adwokatów, analogiczną jak w procesie cywilnym. Rzecz jednakże w tym, iż trybunały kościelne nie korzystają z prerogatyw, jakie przysługują sądownictwu świeckiemu. Ograniczenie to dotyczy m.in. możliwości pozyskiwania dokumentów zawierających informacje objęte tzw. ochroną danych osobowych, jak chociażby urzędowe dokumenty medyczne, które w przypadku prowadzenia postępowania - zwłaszcza z tytułu określonego w kan. 1095, 1084 czy $1103 \mathrm{KPK}$ - mogą mieć znaczenie kluczowe dla rozstrzygnięcia niektórych spraw małżeńskich.

W odniesieniu do tych dokumentów podnieść należy, iż norma art. 40 ust. 1 ustawy o zawodach lekarza i dentysty z dnia 5 grudnia 1996 r. $^{2}$ stanowi, iż lekarz obowiązany jest do zachowania tajemnicy lekar-

${ }^{1}$ W dniu 31 grudnia 2007 r. w polskich sądach kościelnych toczyło się 7217 spraw o nieważność małżeństwa, podczas gdy tego samego dnia w 2003 r. odnotowano 4835 spraw, zaś na końcu 1997 r. - 3483 sprawy (zob. P. MALEcha, Polski wymiar sprawiedliwości widziany przez pryzmat Sygnatury Apostolskiej, [w:] T. Rozkrut (red.), Orzecznictwo rotalne w praktyce sądowej Kościoła, Tarnów 2010, s. 22).

2 Dz. U. z 2005, nr 226, poz. 1943 z późn. zmn. 
skiej, obejmującej informacje związane z pacjentem, przy czym tajemnica lekarska rozciąga się - jak wynika z art. 14 ust. 1 i 2 oraz art. 23 ust. 2 ustawy o prawach pacjenta i rzeczniku praw pacjenta z dnia 6 listopada 2008 r. $^{3}$ - na wszelką dokumentację lekarską, zawierającą informacje dotyczące pacjenta. Uchylenie tajemnicy lekarskiej może nastąpić wówczas, gdy m.in. tak stanowią ustawy. Ustawą taką jest ustawa z 17 listopada 1964 r. Kodeks postępowania cywilnego ${ }^{4}$, który w art. $248 \S 1$ stanowi, iż każdy obowiązany jest przedstawić na zarządzenie sądu w oznaczonym terminie i miejscu dokument znajdujący się w jego posiadaniu i stanowiący dowód faktu istotnego dla rozstrzygnięcia sprawy, chyba, że dokument zawiera tajemnicę państwową. Lekarz ma zatem obowiązek przedstawienia stosownej dokumentacji na żądanie sądu powszechnego, zaś sposób jej udzielania określają przepisy rozporządzenia Ministra Zdrowia z dnia 30 lipca 2001 r. w sprawie rodzajów indywidualnej dokumentacji medycznej, sposobu jej prowadzenia oraz szczególnych warunków jej udostępniania ${ }^{5}$. Wobec jednakże sądów kościelnych lekarz nadal związany jest tajemnica, która nie ulega uchyleniu, gdyż postępowanie przed sądami kościelnymi nie zostało uregulowane ustawą i nie istnieje żaden przepis szczególny, który zezwalałby na udostępnienie dokumentacji medycznej w procesie kanonicznym. Sam pacjent może domagać się wydania mu dokumentacji medycznej, która go dotyczy, jednakże nie ma on możliwości otrzymania dokumentów dotyczących byłego małżonka. Oznacza to, iż w przypadku, gdy jedna ze stron postępowania przed sądem kościelnym nie wyraża woli uczestniczenia w procesie i nie jest zainteresowana dostarczaniem dowodów, sąd kościelny nie ma możliwości bezpośredniego pozyskania dowodu, i to nawet jeśli jego znaczenie dla wyniku sprawy byłoby rozstrzygające. Skoro zatem dokumentacja medyczna mająca służyć jako dowód w procesie kanonicznym nie może być pozyskana dla tego procesu ani przez stronę i jej adwokata, ani przez trybunał kościelny, natomiast byłaby ona dostępna dla sądu powszechnego, rodzi się pytanie, czy w tego rodzaju układzie sytuacyjnym trybunał kościelny może korzystać z pomocy sądu powszechnego. Zagadnienie to było przedmiotem rozważań na wspól-

\footnotetext{
3 Dz. U. z 2009, nr 52, poz. 417 z późn. zmn.

${ }^{4}$ Dz. U. z 1964, nr 43, poz. 293 z późn. zmn.

5 Dz. U. z 2001, nr 83, poz. 903.
} 
nych posiedzeniach Kościelnej Komisji Konkordatowej i Rządowej Komisji Konkordatowej w latach 2003-20056, a nawet stanowiło temat interpelacji poselskiej ${ }^{7}$, jednakże wciąż pozostaje zagadnieniem problematycznym tak dla kanonistów, jak i sędziów świeckich ${ }^{8}$.

Rozstrzygnięcie przedmiotowej kwestii miałoby niebagatelne znaczenie dla praktyki orzeczniczej sądów kościelnych, zaś stronom i ich adwokatom dawałoby jasność co do obszaru i granic ich inicjatywy dowodowej. Zagadnienie dopuszczalności współpracy sądów kościelnych i świeckich w zakresie pozyskiwania dokumentów medycznych dla potrzeb małżeńskiego procesu kanonicznego w naturalny sposób prowokuje do dociekań o charakterze szerszym, tj. dotyczącym ogólnie możliwości współpracy sądownictwa kościelnego i świeckiego w zakresie rekwizycji. Artykuł niniejszy stanowi zatem próbę odpowiedzi na pytanie: czy w świetle obowiązujących przepisów pomoc sądowa pomiędzy trybunałami kościelnymi a sądami powszechnymi w Polsce w kanonicznych procesach małżeńskich jest, co do reguły, dopuszczalna prawnie, a jeśli tak, to na jakich zasadach winna się ona odbywać?

Artykuł został podzielony na trzy części. Pierwsza część dotyczy wyjaśnienia istoty rekwizycji zarówno z punktu widzenia prawa kościelnego, jak i polskiego. W drugiej części została poddana analizie prawnej możliwość współpracy sądów kościelnych z sądami powszechnymi. W tej części została przedstawiona również próba odpowiedzi na pytanie o wartość dowodową w procesie kanonicznym materiałów pozyskanych od sądów świeckich, a także o podstawę prawną do wykonywania rekwizycji sądów kościelnych przez sądy

${ }^{6}$ A. Brzemia-Bonarek, Pomoc sqdowa pomiędzy sqdami kościelnymi a państwowymi $w$ celu uzyskania dokumentów niedostęnych dla strony w kanonicznym procesie matzeńskim (analiza prawna zagadnienia i propozycje ,, de lege ferenda”) [w:] Sędzia i pasterz. Księga pamiątkowa w 50-lecie pracy ks. Remigiusza Sobańskiego w Sądzie Metropolitalnym w Katowicach (1957-2007), (red.) H. TYPAŃSKA, Katowice 2007, s. 49.

${ }^{7}$ Interpelacja nr 10991 wniesiona 20 sierpnia 2009 r. przez posła Tomasza Kamińskiego do Ministra Sprawiedliwości w sprawie procedury umożliwiającej uzyskiwanie danych medycznych przez sąd kościelny. Odpowiedzi na tę interpelację udzielił 17 września 2009 r. Piotr Kluz, podsekretarz stanu w Ministerstwie Sprawiedliwości.

${ }^{8}$ Zob. artykuł pt. „Sad powszechny w stużbie Kościoła” zamieszczony w „Gazecie Wyborczej" z dnia 1 lutego 2010 r., s. 8. 
świeckie. Trzecia część zawiera uwagi praktyczne odnośnie do wykonania rekwizycji na wniosek trybunału kościelnego.

\section{Istota rekwizycji}

Pomoc sądowa jest instytucją prawną występującą zarówno w prawie kanonicznym, jak i w prawie polskim. W prawie kanonicznym zagadnienie to reguluje kan. 1418 KPK, który wprost stanowi, iż każdy trybunał ma prawo prosić o pomoc inny trybunał celem przeprowadzenia instrukcji sprawy lub celem zawiadomienia o aktach. Zgodnie zatem z zasadą wyrażoną $\mathrm{w}$ tym kanonie każdy sąd kościelny może zwrócić się do innego sądu kościelnego z wnioskiem o przesłuchanie stron lub świadków, o poszukiwanie dokumentów lub przedmiotów, o podanie do wiadomości akt procesowych itp. wówczas, gdy wnioskowana czynność miałaby być przeprowadzona poza terytorium jego jurysdykcji ${ }^{9}$. Zwrócenie się o wykonanie wymienionych czynności oznacza przekazanie kompetencji do przeprowadzenia czynności procesowych, jednakże nie jest delegowaniem władzy rozstrzygania. W myśl bowiem kan. $135 \S 3$ KPK sędzia nie może delegować władzy rozstrzygania, a jedynie upoważnienie do przygotowania (gromadzenia) materiału dowodowego ${ }^{10}$. Trybunał wezwany obowiązany jest do udzielenia żądanej pomocy; rekwizycję winien wykonać bez zwłoki oraz zgodnie z obowiązującymi przepisami prawa procesowego oraz z przysłaną instrukcją ${ }^{11}$. Kosztami związanymi z wykonaniem rekwizycji trybunał wezwany może obciążyć trybunał wzywający ${ }^{12}$. Dodatkową możliwość w przedmiotowym zakresie przewiduje art. 29 § 2 Instrukcji procesowej „Dignitas connubii”, który wskazuje, iż prośbę w przedmiocie rekwizycji można skierować do biskupa diecezji, w której postulowana czynność miałaby być wykonana. Właściwy w tym zakresie jest biskup diecezjalny, któremu dany sąd podlega ${ }^{13}$. W literaturze trafnie zauważa się, iż kierowanie wniosku o wyko-

9 Zob. Komentarz do Kodeksu Prawa Kanonicznego, (red.) J. KrUKowsKi i in., t. 5, Poznań 2007, s. 31.

${ }^{10}$ Zob. Komentarz do Instrukcji procesowej „,Dignitas connubi”, (red.) T. Rozkrut, Sandomierz 2007, s. 68.

11 Zob. T. Pawluk, Prawo Kanoniczne wedtug Kodeksu Jana Pawła II, t. 4, Doczesne dobra Kościoła. Sankcje w Kościele. Procesy, Olsztyn 1990, s. 181-182.

12 Tamże, s. 182.

13 Komentarz do Instrukcji..., jw., s. 68. 
nanie określonej czynności bezpośrednio do sądu kościelnego, który czynność tę miałby wykonać, wpływa na szybkość postępowania i znajduje oparcie w zasadach ekonomii procesowej, jednakże nie brak i takich głosów, iż tylko biskup może nakazać sądowi wykonanie jakiejkolwiek czynności. Nie kwestionując tej ostatniej tezy, zaznaczyć jednakże trzeba, iż zarówno brzmienie kan. 1418 KPK, jak i art. 29 § 1 i 2 DC nie pozostawia watpliwości, iż regułą winno być bezpośrednie współdziałanie sądów kościelnych, zaś proszenie w tej materii o pomoc biskupa należałoby pozostawić dla wypadków szczególnych.

Natomiast pomoc sądową w prawie polskim normuje art. $44 \S 1-4$ ustawy z dnia 27 lipca 2001 r. Prawo o ustrojów sądów powszechnych $^{14}$. Zgodnie $\mathrm{z}$ regułą wyrażoną $\mathrm{w}$ tym przepisie, w przypadkach przewidzianych w ustawach, sądy obowiązane są wykonywać poszczególne czynności sądowe na żądanie innych sądów oraz innych organów ( $§ 1)$, jak również na żądanie sądów zagranicznych, jeżeli wzajemność jest zapewniona (§ 2). W zakresie przewidzianym w przepisach o postępowaniu cywilnym sądy powszechne obowiązane są wykonywać czynności dowodowe także - i to jest tu istotne (!) - na wniosek organów orzekających innych niż wymienione w $\S 1$ i 2, jeżeli wniosek taki skierowany został przez Ministra Sprawiedliwości (§ 3). Z powyższego wynika zatem, iż pomoc sądowa występuje zarówno w obrocie krajowym, jak i w obrocie z zagranicą ${ }^{15}$. Polega ona na przeprowadzeniu - na zlecenie innego sądu krajowego lub zagranicznego albo organu pozasądowego, gdy taką możliwość przewidują przepisy odrębne lub akty prawa międzynarodowego - określonego dowodu (pomoc prawna sensu stricto) lub na wykonaniu każdej in-

${ }^{14}$ Dz. U. z 2001, nr 98, poz. 1070 z późn. zmn. (dalej jako u.s.p.).

15 Tryb postępowania w sprawach o udzielenie pomocy prawnej w obrocie zagranicznym określa rozporządzenie Ministra Sprawiedliwości z 28 stycznia 2002 r. (Dz. U. z 2002, nr 17, poz. 164 z późn. zmn.) w sprawie szczegółowych czynności sądów w sprawach z zakresu międzynarodowego postępowania cywilnego oraz karnego w stosunkach międzynarodowych. W wykonywaniu zagranicznej pomocy prawnej w sprawach cywilnych podstawowe znaczenie mają konwencje haskie z 1954 r., 1965 r. i 1970 r. oraz Rozporządzenie Rady Wspólnoty Europejskiej nr 1348/2000 z dnia 29 maja 2000 r. w sprawie doręczania w państwach członkowskich sądowych i pozasądowych dokumentów w sprawach cywilnych i handlowych, a także Rozporządzenie Rady Wspólnoty Europejskiej nr 1206/2001 z dnia 28 maja 2001 r. w sprawie współpracy między sądami państw członkowskich przy przeprowadzaniu dowodów w sprawach cywilnych lub handlowych. 
nej czynności zleconej, jak np. doręczenie pisma, udzielenie informacji, udostępnienie dokumentu (pomoc prawna sensu largo) ${ }^{16}$. Sięganie po rekwizycję sądową, będące odstępstwem od zasady bezpośredniości, ma miejsce wówczas, gdy przeprowadzenie dowodu lub wykonanie innej czynności zleconej napotyka na trudne do przezwyciężenia przeszkody wynikające albo z charakteru dowodu, albo ze znacznej niedogodności w jego przeprowadzeniu, bądź też gdy miałoby to powodować koszty niewspółmierne do przedmiotu sporu lub niezasadne społecznie ${ }^{17}$. Do organów pozasądowych, o których mowa w wymienionym art. 44 u.s.p., uprawnionych do zwracania się do sądów powszechnych o rekwizycję należą na postawie art. 706 k.p.c. sądy polubowne, a także okręgowe sądy lekarskie, lekarsko-weterynaryjne, aptekarskie oraz pielęgniarek i położnych ${ }^{18}$ oraz Urząd Zamówień Publicznych ${ }^{19}$ i Prezes Urzędu Konkurencji i Konsumentów ${ }^{20}$. Odnośnie do kwestii związanych z samą procedurą wykonywania rekwizycji, z uwagi na ramy zakreślone tematem niniejszej publikacji należy powiedzieć, iż takie zagadnienia jak redagowanie odezwy, przesyłanie akt i zaliczki, określenie odległości pomiędzy sądem wezwanym i sądem wzywającym, uzasadniające zlecenie przeprowadzenia dowodu, jak również zwracanie odezwy oraz przesyłanie jej innemu sądowi w przypadku stwierdzenia swej niewłaściwości regulują przepisy $\S 99-105$ Rozporządzenia Ministra Sprawiedliwości z dnia 23 lutego 2003 r. Regulamin urzędowania sądów powszechnych ${ }^{21}$.

16 T. EReciński, J. Gudowski, J. IwUlski, Prawo o ustroju sq̨ów powszechnych. Ustawa o Krajowej Radzie Sadownictwa. Komentarz, Warszawa 2010, s. 154.

17 J. Cygara, Pomoc sqdowa w sprawach cywilnych, [w:] Problemy wymiaru sprawiedliwości, (red.), Warszawa 1979, nr 17, s. 5.

18 Stanowi o tym art. 58 ust. 2 ustawy z 17 maja 1989 r. o izbach lekarskich (Dz. U. z 1989, nr 30, poz. 158); art. 63 ust. 2 ustawy z 21 grudnia 1990 r. o zawodzie lekarza weterynarii i izbach lekarsko-weterynaryjnych (Dz. U. z 2002, nr 187, poz. 1567); art. 63 ust. 2 ustawy z 19 kwietnia 1991 r. o izbach aptekarskich (Dz. U. z 2003, nr 9, poz. 108) oraz art. 55 ust. 2 ustawy z 19 kwietnia 1991 r. o samorządzie pielęgniarek i położnych (Dz. U. z 1991, nr 41, poz. 178).

19 Wskazuje na to art. 87 ustawy z 10 czerwca 1994 r. o zamówieniach publicznych (Dz. U. z 2002, nr 72, poz. 664).

${ }^{20}$ Wynika to z art. 235 k.p.c. i art. 81 ustawy z 15 grudnia 2000 r. o ochronie konkurencji i konsumentów (Dz. U. z 2003, nr 86, poz. 804); wszystkie podmioty wskazane powyżej wymienione zostały [w:] T. Ereciński, J. Gudowski, J. Iwulski, Prawo o ustroju ..., j.w., s. 155-156.

21 Dz. U. z 2007, nr 38, poz. 249. 


\section{Współpraca sądów kościelnych z sądami powszechnymi w przedmiocie rekwizycji - analiza prawna}

Wyrażona w art. 1 Konkordatu ${ }^{22}$ zasada niezależności i autonomii Kościoła i państwa oznacza uznanie przez każdą z tych dwóch społeczności własnego systemu prawa oraz możliwości rządzenia się nim w swoim porządku. Nie oznacza to jednakże całkowitej izolacji obu tych struktur prawnych, zwłaszcza że oba te porządki w pewnych wymiarach przenikają się, a sprawy z pogranicza prawa polskiego i kanonicznego pojawiają się $\mathrm{W}$ praktyce sądowniczej ${ }^{23}$. Pomoc sądowa pomiędzy sądami kościelnymi i państwowymi nie została uregulowana expressis verbis w żadnym akcie prawnym. Rozważając przedmiotowe zagadnienie odpowiedzieć zatem należy na dwa zasadnicze pytania: po pierwsze - czy trybunał kościelny w kanonicznym procesie małżeńskim może zwrócić się do sądu powszechnego z wnioskiem o pomoc w pozyskaniu dowodu (i czy byłoby to celowe, tj. czy tak zdobyty dowód mógłby zostać wykorzystany procesowo) i po drugie czy w takim układzie procesowym sąd powszechny miałby podstawę prawną do wykonania wnioskowanych czynności. Analiza omawianego problemu nie byłaby pełna bez odpowiedzi również i na trzecie pytanie, a mianowicie, czy dopuszczalna byłaby rekwizycja w układzie odwrotnym, tj. taka, w której z wnioskiem o pomoc zwracałby się do sądu kościelnego sąd powszechny.

\subsection{Dopuszczalność pozyskania dowodu w kanonicznym procesie} małżeńskim za pośrednictwem sądu powszechnego

Zwrócenie się przez sąd kościelny do sądu powszechnego z wnioskiem o pomoc w uzyskaniu dowodu niewatpliwie nie byłoby rekwizycją w rozumieniu powołanego wcześniej kan. 1418 KPK, gdyż ten dotyczy współpracy wyłącznie pomiędzy trybunałami kościelnymi. Brak wyraźnej podstawy prawnej nie oznacza jednak, że tego rodzaju aktywność procesowa byłaby zabroniona i sprzeczna z zasadami prawa kanonicznego. Podstawową zasadą kanonicznego procesu o stwier-

22 Konkordat między Stolicą Apostolską a RP podpisany w Warszawie 28 lipca 1993 r. (Dz. U. z 1998, nr 51, poz. 318), ratyfikowany ustawą z 8 stycznia 1998 r. (Dz. U. z 1998, nr 12, poz. 42).

${ }^{23}$ L. Świto, Moc dowodowa dokumentów kościelnych $w$ procedurze cywilnej, PK 53(2010), nr 1-2, s. 249-272. 
dzenie nieważności małżeństwa jest bowiem dotarcie do prawdy i to prawdy o istnieniu lub nieistnieniu sakramentu, a co za tym idzie - troska o zbawienie człowieka. Proces kanoniczny w dążeniu do prawdy dotyka najważniejszego celu, tj. celu eschatologicznego, zaś prawda o konkretnym małżeństwie leży w interesie całej, bosko-ludzkiej wspólnoty Kościoła ${ }^{24}$. Jeśli zatem zwrócenie się o pomoc do sądu powszechnego w uzyskaniu dowodu koniecznego dla wydania sprawiedliwego orzeczenia jest działaniem w imię prawdy, to trudno byłoby wywieść wniosek o niedopuszczalności tego rodzaju działań w oparciu o brzmienie kan. $220 \mathrm{KPK}$. Nie ulega watpliwości, iż przepis ten statuując zasadę ochrony dobrego imienia i obowiązek przestrzegania prawa do poszanowania godności osobistej każdego człowieka, chroni jedną z podstawowych wartości ludzkich, jednakże nie można uznać, by $\mathrm{w}$ optyce procesowej norma ta miała charakter nadrzędny nad prawda. Tym bardziej, iż norma ta zabrania bezprawnego (podkreślenie L.S.) naruszania prawa do intymności, co wskazuje, iż nie ma ona charakteru bezwzględnego i ustawodawca dopuszcza takie sytuacje, w którym owo prawo może doznać ograniczenia. Nie sposób przy tym nie zauważyć, że prawo do prywatności i ochrona intymności ludzkiej podlega w procesie małżeńskim wyjątkowej ochronie. Gwarantem tej ochrony jest rozbudowana i występująca w wielu aspektach, zasada tajności procesu małżeńskiego ${ }^{25}$. Nie sposób wreszcie nie podnieść i tego, że poza omawianą zasadą w procesie kanonicznym występuje również inna, niezmiernie istotna zasada wyrażona w kan. $221 \S 1$ i 2 KPK, jaka jest prawo każdej ze stron do sprawiedliwego, czyli zgodnego z prawdą obiektywna, wyroku.

Czynność procesowa w postaci zwrócenia się do sądu powszechnego $\mathrm{z}$ wnioskiem o pomoc $\mathrm{w}$ pozyskaniu dowodu nie jest, sama w sobie, objęta „zakazem dowodowym” wymienionym w kan. 1548 $\S 2 \mathrm{KPK}$. W pozyskanych w ten sposób dowodach trudno byłoby dopatrzeć się również niegodziwości, o której mowa w kan. $1527 \S 1$ KPK. Nie wchodząc w głębię nader złożonego zagadnienia, jakim jest problematyka godziwości dowodów, należy powiedzieć, iż skoro zdo-

${ }^{24}$ A. Brzemia-Bonarek, Dopuszczalność dowodów zdobytych w sposób niegodziwy w kanonicznym procesie o stwierdzenie nieważności matzeństwa, Katowice 2007, s.117.

25 Zob. KPK: kan. 471 n. 2, kan. 486, kan. 1455, kan. 1457, kan. 1470 § 1, kan. 1475, kan. $1598 \S 1$. 
bycie dowodu w omawianym przypadku motywowane jest godziwym celem i jest zgodne z państwowym porządkiem prawnym (dowód nie jest nielegalny), to trudno uznać, by dowód ów był niegodziwy z uwagi na taką metodę jego pozyskania ${ }^{26}$. W świetle powyższego stwierdzić należy, że jakkolwiek nie ulega wattpliwości, iż przepisy KPK zawierają reguły, które sprawiają, że nawet prawda jako cel procesu podlega ograniczeniom z uwagi na możliwość użycia niektórych dowodów, to jednakże nie można uznać, by tego rodzaju ograniczenia odnosiły się do omawianej pomocy sądowej. Dopuszczalność takiej pomocy można natomiast wywnioskować m.in. z interpretacji kan. 1530, 1452 i 1608 KPK, które nakładają na sędziego obowiązek poszukiwania prawdy o sądzonym fakcie (małżeństwie) i zobowiązują go - pod pewnymi warunkami - do aktywności w postępowaniu dowodowym. Gdyby sędzia posiadał informację o istotnym dla rozstrzygnięcia dowodzie, który mógłby pozyskać przy pomocy sądu powszechnego, lecz z takiej możliwości nie skorzystał, nie sposób byłoby uznać, że uczynił on wszystko dla osiagnięcia pewności moralnej co do ważności sądzonego przez siebie małżeństwa. Uwagę tę odnieść należy zarówno do możliwości pozyskania dowodów w postaci dokumentów, jak i informacji pochodzących z osobowych źródeł dowodowych.

Analizując kwestię dopuszczalności zwrócenia się do sądu powszechnego o przesłuchanie w ramach pomocy świadka (strony), z góry zaznaczyć należy, iż zagadnienie to niewątpliwie należy do polemicznych. Pewne jest jednakże, że czynność tego rodzaju mieści się w zakresie czynności wykonywanych w rekwizycji i to zarówno w procedurze kanonicznej, jak i świeckiej. Nie ulega też wątpliwości, że ustawodawca kościelny, określając w kan. 1527 § 1 KPK dowody dopuszczalne w procesie kanonicznym, zawarł regułę ogólną, zezwalającą na przyjęcie dowodów jakiegokolwiek rodzaju, które byłyby przydatne dla rozstrzygnięcia sprawy. Odnosząc tę uwagę do dowodu z zeznań osoby, która $\mathrm{w}$ ramach rekwizycji przesłuchana zostałaby przed sądem państwowym, stwierdzić należy, iż jakkolwiek dowód taki nie byłby dowodem z przesłuchania świadka (strony) w rozumieniu kan. 1547 KPK, gdyż taki walor może przysługiwać jedynie tym zeznaniom, które złożone zostały przed trybunałem kościelnym bądź osobami przez trybunał do tego umocowanymi, to jednakże zeznania

${ }^{26}$ A. Brzemia-Bonarek, Dopuszczalność..., jw., s. 58. 
tego rodzaju mogłyby stanowić ,inny” dowód, o którym mowa w wymienionym kan. 1527 § 1 KPK. Taki dowód, jakkolwiek dotknięty pewną ułomnością, niewątpliwie mógłby przyczynić się do wzbogacenia materiału aktowego, służąc pełniejszemu odkryciu prawdy. Za interpretacją dopuszczającą możliwość zwrócenia się o przesłuchanie świadka (strony) do sądu powszechnego zdaje się przemawiać również interpretacja kan. $1528 \mathrm{KPK}$. Jeśli bowiem świadek (strona) ma prawo złożyć swoje zeznania służące jako dowód w procesie małżeńskim m.in. przed notariuszem publicznym, to trudno byłoby znaleźć powody, dla których nie mógłby uczynić tego przed sądem powszechnym, tym bardziej że doktryna wyraźnie opowiada się za wykładnią rozszerzającą kan. $1528 \mathrm{KPK}^{27}$.

Nie wykluczając zatem dopuszczalności rekwizycji w omawianym zakresie, wyraźnie podkreślić należy, że pomoc tego rodzaju mogłaby mieć zastosowanie jedynie w wypadkach szczególnych i w żadnej mierze nie mogłaby być uznana za powszechny, procesowy „wytrych” służący wydobyciu zeznań od opornych. Udział w sprawie zarówno strony, jak i świadka jest kwestią jego wyboru i sumienia, którego łamać nie godzi się nawet w słusznej sprawie. Zwrócenie się o pomoc w przesłuchaniu danej osoby byłoby zasadne wówczas, gdyby to nie sam fakt wypowiedzenia się w sprawie był dla tej osoby problematyczny, ale to, że zeznania owe miałyby zostać złożone przed trybunałem kościelnym. Jeśli odmowa stawiennictwa przed sądem kościelnym wynika z przyczyn ideologicznych, natomiast świadek (lub strona) wyraża gotowość złożenia zeznań przed sądem powszechnym, podjęcie próby pozyskania informacji w drodze pomocy sądowej wydaje się w takim przypadku zasadne i godziwe.

Reasumując, stwierdzić należy, iż zaprezentowane powyżej uwagi dotyczące dopuszczalności rekwizycji do sądu powszechnego, w żadnym stopniu nie oznaczają zmiany akcentów w zakresie inicjatywy dowodowej i bynajmniej nie oznaczają, iż sędzia w inicjatywie dowodowej winien zastępować strony i że to na nim spoczywa obowiązek poszukiwania dowodów. Ustawodawca kościelny w kan. 1526 $\S 1$ KPK jednoznacznie określił bowiem, iż obowiązek udowodnienia twierdzeń spoczywa na tym, kto domaga się uznania danego faktu

${ }^{27}$ Zob. Komentarz do Kodeksu..., jw., s. 179-180. 
przez sąd i wyprowadzenia z niego skutków prawnych ${ }^{28}$. Aktywność w postępowaniu dowodowym spoczywa zatem przede wszystkim na stronach i wniosku powyższego w niczym nie zmienia kwestia omawianej rekwizycji. Oczywiste jest przy tym, iż rekwizycja do sądu powszechnego nie mogłaby zostać zrealizowana bezpośrednio przez samą stronę czy jej adwokata, gdyż jest ona czynnością sądową i w naturalny sposób wymaga aktywności sędziowskiej. Jednakże faktu tego nie można traktować ani jako okoliczności zwalniającej strony z aktywności dowodowej, ani też jako przesłanki obligującej sędziów kościelnych do takiego poszukiwania dowodów.

\subsection{Dopuszczalność wykonania przez sąd powszechny pomocy sądowej z wniosku sądu kościelnego}

Sądy kościelne nie należą do sądów w rozumieniu ustawy Prawo o ustroju sądów powszechnych i dlatego też do podmiotów tych nie odnosi się regulacja dotycząca rekwizycji sądowej określonej w art. 44 $\S 1$ i 2 wymienionej ustawy. Nie oznacza to jednakże, iż w przepisach prawa polskiego brak jest podstawy, która dopuszczałaby wykonanie przez sąd powszechny rekwizycji sądu kościelnego. Pomijając rozważania, czy sąd kościelny winien być w zakresie rekwizycji traktowany jako sąd zagraniczny ${ }^{29}$, stwierdzić należy, iż możliwość tego rodzaju rekwizycji przewiduje cytowany wyżej art. $44 \S 3$ u.s.p., który jednoznacznie zobowiązuje sądy powszechne, na zasadach tam określonych, do wykonywania czynności dowodowych zleconych przez inne organy orzekające. Przynależność do pozasądowych organów orzekających wynika bądź to - jak wskazano wyżej w rozdziale $1-$ z regulacji zawartej bezpośrednio w przepisach Kodeksu postępowania cywilnego, bądź w odesłaniach do tego aktu prawnego zamieszczonych w poszczególnych ustawach, jak ma to miejsce m.in. w ustawie o izbach lekarskich czy w ustawie o samorządzie pielęgniarek i położnych. W przepisach KPK nie ma odesłania do procedury cywilnej, a działalność trybunałów kościelnych nie jest regulowana ustawa, jednak to, że sądy kościelne są organami orzekającymi w znaczeniu wyżej podanym, nie może budzić wątpliwości. Abstrahując od tego,

28 Tamże, s. 176.

${ }^{29}$ Tego rodzaju rozważania przeprowadza A. Bonarek-Brzemia we wskazanym wyżej artykule „Pomoc sądowa...” (s. 44-48). W konkluzji możliwość takiej interpretacji autorka kwestionuje. 
iż ustawa o ustroju sądów powszechnych nie podaje żadnej definicji organów orzekających ani też nie zawiera żadnego katalogu tego rodzaju podmiotów, stwierdzić należy, iż to, że trybunały kościelne są organami orzekającymi, wynika zarówno z samej oczywistości ich zadań i funkcji, jak również z brzmienia Konkordatu. Sądy kościelne nie działają na terenie RP w sposób ukryty i nielegalnie, poza wiedzą, świadomością i zgodą państwa. Kościół katolicki pełni swą jurysdykcję w oparciu o umocowanie wynikające $\mathrm{z}$ umowy pomiędzy państwem i Kościołem. Istotne jest przy tym, iż państwo nie tylko „przyjęło do wiadomości” istnienie jurysdykcji kościelnej, ale w art. 5 Konkordatu wyraźnie zobowiązało się do zapewnienia Kościołowi swobodnego i publicznego pełnienia jego misji, z wykonywaniem jurysdykcji łącznie. Co więcej, w odniesieniu do spraw małżeńskich, art. 10 ust. 5 Konkordatu sygnalizuje nawet potrzebę wzajemnego powiadamia się obu stron, tj. kościelnej i państwowej, o orzeczeniach wydanych w trybie art. 10 ust. 3 i 4 Konkordatu, postulując ewentualne ustalenie szczegółów w tym zakresie w ramach art. 27 Konkordatu $^{30}$. Skoro zatem w tak doniosłym akcie prawnym jak Konkordat, który wszak jest umową międzynarodową ratyfikowaną ustawą, państwo nie tylko zezwoliło na istnienie na jego terytorium jurysdykcji kościelnej, ale wyraźnie dostrzegło walor informacyjny orzeczeń trybunałów kościelnych w procesach świeckich, dopuszczając nawet w odniesieniu do tych dokumentów możliwość pewnej współpracy pomiędzy sądami kościelnymi i świeckimi ${ }^{31}$, to teza, iż sądy kościelne nie są organami orzekającymi w znaczeniu przepisów o rekwizycji, byłaby całkowicie irracjonalna. Powyższa analiza przepisów zdaje się jednoznacznie wskazywać, że sądy kościelne nie tylko są organami orzekającymi w rozumieniu art. 44 ust. 3 u.s.p., ale również, że wykonanie przez sąd powszechny wniosku sądu kościelnego o pomoc w pozyskaniu dowo-

${ }^{30}$ Wprawdzie do wspomnianego uregulowania szczegółów w trybie art. 27 Konkordatu do chwili obecnej nie doszło, niemniej jednak art. 10 ust. 5 Konkordatu nie został w żadnym zakresie ani formie zakwestionowany, co zdaje się wskazywać, iż prawodawca polski orzeczeniom sądów kościelnych nadał cechę zaufania publicznego (zob. L. Świto, Moc dowodowa..., jw., s. 268).

31 Zapis powyższy w żadnej mierze nie dotyczy wzajemnego uznawania wyroków, co jest wnioskiem powszechnie przyjętym w doktrynie (zob. m.in. P. MAJER, Uznawanie przez państwo wyroków sqdów kościelnych $w$ sprawach matżeńskich. Czy byłoby pożytecznie przyjęcie takiego systemu w Polsce?, [w:] A. MezGlewski, Funkcje..., jw., s. 423). 
du nie tylko w niczym nie narusza prawa państwowego, ale jest w pełni zgodne z obowiązującym w Polsce porządkiem prawnym.

Do takiego wniosku prowadzi także analiza kontekstu szerszego, tj. relacji pomiędzy państwem a Kościołem katolickim, zwłaszcza w aspekcie spraw małżeńskich. Zważywszy na ramy zakreślone tematem tej publikacji, zasygnalizować jedynie należy, iż Kościół katolicki w Polsce jest nie tylko osobą prawa publicznego, ale podmiotem posiadającym osobowość prawną uznaną (recognitio) w sposób jednoznaczny przez państwo, a zatem bytem wyposażonym w taki atrybut, który pozwala mu, jako podmiotowi praw i obowiązków w relacji do innych podmiotów, uczestniczyć w danym porządku prawnym ${ }^{32}$. Obecność Kościoła w życiu publicznym państwa jest zatem nie tylko faktem historycznym i współczesnym, ale również faktem prawnym, zaś udział Kościoła w wykonywaniu spraw publicznych reguluje zarówno kościelne, jak i państwowe prawo publiczne, w tym ustawa z 17 maja 1989 r. o stosunku państwa do Kościoła katolickiego w Rzeczypospolitej Polskiej ${ }^{33}$. W doktrynie kościelnej i świeckiej podkreśla się, iż relacje instytucjonalne na płaszczyźnie Kościół-państwo opierają się na zasadzie współdziałania. Konstytucja Gaudium et spes w nr 76 stanowi, iż ,Wspólnota polityczna i kościół są w swoich dziedzinach od siebie niezależne i autonomiczne. Obie jednak wspólnoty, choć z różnego tytułu, służą powołaniu jednostkowemu i społecznemu tych samych ludzi. Tym skuteczniej będą wykonywać tę służbę dla dobra wszystkich, im lepiej będą rozwijać między sobą zdrowe współdziałanie, uwzględniając także okoliczności miejsca i czasu", zaś Konstytucja Rzeczypospolitej Polskiej z 1997 r. w art. 25 ust. 3 stwierdza, że „stosunki między państwem a kościołami i innymi związkami wyznaniowymi są kształtowane na zasadach poszanowania ich autonomii oraz wzajemnej niezależności każdego w swoim zakresie, jak również współdziałania dla dobra człowieka i dobra wspólnego"34. Współdziałanie to odbywa się na płaszczyźnie spraw należących do tzw. forum mieszanego (rei mixti fori), a zatem w zakresie takich spraw, w których kompetentny jest i Kościół, i państwo, aczkolwiek

32 Zob. J. Krukowski, Polskie prawo wyznaniowe, Warszawa 2007, s. 103.

33 Dz. U. z 1989, nr 29, poz. 154.

34 Zob. R. Mojak, Kościół a sprawy publiczne $w$ demokratycznym państwie. Podstawy doktrynalne oraz zasady prawne współdziałania Kościoła i państwa w sferze prawa publicznego, [w:] A. Mezglewski, Funkcje..., jw., s. 63. 
każdy z tych podmiotów sprawy te realizuje w sposób właściwy sobie. Do spraw tego rodzaju, obok m.in. udzielania pomocy społecznej czy też podejmowania działań zmierzających do ochrony dóbr kultury i dziedzictwa narodowego, należą czynności związane z zawieraniem małżeństw cywilnych w formie wyznaniowej. Klasycznym przykładem „spraw mieszanych”, które podlegają jednocześnie władzy kościelnej i państwowej, jest również szeroko pojmowana ochrona małżeństwa i rodziny ${ }^{35}$. Z zestawienia kwestii kościelnego orzekania w przedmiocie małżeństwa $\mathrm{z}$ analogicznym postępowaniem świeckim widać wyraźnie, iż obie te regulacje dotykają takiej materii, w której występuje zarówno kompetencja Kościoła, jak i państwa, przy czym w obu tych porządkach małżeństwo i rodzina są dobrem chronionym. Jednoznacznie wynika to również z treści art. 11 Konkordatu, który wprost stwierdza, iż „Układające się Strony deklarują wolę współdziałania na rzecz obrony i poszanowania instytucji małżeństwa i rodziny będących fundamentem społeczeństwa".

Jeśli zatem państwo powierzyło Kościołowi wykonywanie zadań publicznych, i to w takim wymiarze, iż w literaturze można spotkać pogląd, że „(...) Rzeczpospolita Polska coraz częściej włącza Kościół w publiczną administrację świadczącą"36, i jeśli weźmie się pod uwagę, iż wierni Kościoła katolickiego w Polsce są także obywatelami tego kraju, to brak jest - również i w tym obszarze analizy - jakichkolwiek racji, które mogłyby uzasadniać odmowę udzielenia przez sądy powszechne pomocy sądom kościelnym w przedmiocie omawianej rekwizycji.

\subsection{Rekwizycja z wniosku sądu powszechnego?}

Rozważając zagadnienie rekwizycji w układzie, w którym to trybunał kościelny miałby być wezwany do udzielenia pomocy sądowi powszechnemu, stwierdzić należy, iż rekwizycja tego rodzaju nie tylko nie znajduje podstawy prawnej w żadnym z obu tych systemów, ale również trudno byłoby uznać ją za celową i mającą jakiekolwiek praktyczne zastosowanie. Zważywszy bowiem chociażby na podniesione wyżej ograniczenia w możliwościach dowodowych trybunałów

${ }^{35}$ Zob. J. Krukowski, Kościót i państwo. Podstawy relacji prawnych, Lublin 2000, s. 313 .

${ }^{36}$ B. Rakoczy, Ustawa o stosunku Państwa do Kościoła Katolickiego w Polsce. Komentarz, Oficyna 2008, s. 18. 
kościelnych, nie sposób uznać, by w zakresie pozyskania dowodów jakikolwiek sąd kościelny mógł uczynić więcej niż sąd powszechny. Teza ta jest tym bardziej oczywista, jeśli weźmie się pod uwagę fakt, iż trybunały kościelne nie dysponują żadnymi środkami przymusu, w odróżnieniu od sądów powszechnych, a zatem nie mają też żadnych możliwości skutecznego egzekwowania dowodów. Obowiązujące w KPK reguły dotyczące tajności procesu w sprawach małżeńskich nie dopuszczają jakiejkolwiek możliwości wydawania akt ani stronom (poza skargą i wyrokiem), ani sądom państwowym (i to nawet w tych krajach, gdzie - jak np. we Włoszech - orzeczenia kościelne mogą uzyskać skuteczność w porządku cywilnym) ${ }^{37}$, co jest dodatkowym argumentem wskazującym na to, iż rekwizycja w tego rodzaju układzie byłaby całkowicie bezprzedmiotowa.

\section{Wykonanie odezwy trybunału kościelnego - uwagi praktyczne}

Analizując kwestię dotyczącą ,technicznej” strony wykonania rekwizycji, o której mowa wyżej w pkt. 2.1 i 2.2, na wstępie zaznaczyć należy, iż tego rodzaju działanie sąd kościelny może podjąć zarówno z własnej inicjatywy, jak i na wniosek stron oraz ich adwokatów. W tym drugim przypadku wspomniany wniosek nie może mieć dla trybunału charakteru wiążącego, lecz winien być traktowany jedynie w kategoriach postulatu dowodowego i podlegać ocenie trybunału. Nawet jeśli w subiektywnym przekonaniu wnioskodawcy zwrócenie się z odezwą do sądu powszechnego jest konieczne, to o tym, czy procedurę tę uruchomić, winien decydować trybunał rozpoznający sprawę po przeanalizowaniu argumentacji zawartej we wniosku i po rozważeniu, czy czynność ta byłaby w danym postępowaniu celowa. Postulując rekwizycję, wnioskodawca winien zatem nie tylko jasno określić, jaki dowód w wyniku tej pomocy miałby być zdobyty i jakie jest jego znaczenie dla rozstrzygnięcia sprawy, ale również winien istnienie tego dowodu uprawdopodobnić. Trudno bowiem byłoby uznać za rzeczowy wniosek o zwrócenie się o pomoc do sądu powszechnego z prośbą np. o pozyskanie dokumentacji medycznej w sytuacji, gdyby zgłaszająca taki postulat strona nie potrafiła wskazać, z jakiej placówki owe dokumenty miałyby pochodzić bądź też w ogóle uwiarygodnić tego, że osoba, której dokumenty te mają dotyczyć, z pomo-

37 A. Brzemia-Bonarek, Pomoc sqdowa..., jw., s. 47. 
cy medycznej korzystała. Skoro bowiem, jak podkreślono to wyżej, trybunał kościelny nie może (co do zasady) „wyręczać” stron w inicjatywie dowodowej, to tym bardziej nie można żądać, by czynił to sąd powszechny.

Podejmując decyzję o uruchomieniu procedury rekwizycyjnej do sądu powszechnego i redagując treść prośby, trybunał kościelny w miarę możliwości winien dostosować jej formę do wymogów § 99 pkt. 1 Regulaminu urzędowania sądów powszechnych, co dotyczy zwłaszcza wymogu, by zlecenie przeprowadzenia dowodu określało dokładnie, jaka czynność miałaby zostać wykonana, a w razie potrzeby przytaczałoby fakty i okoliczności, na które sąd wezwany winien zwrócić szczególną uwagę. Oczywiste jest przy tym, iż omawiane zlecenie wykonania czynności nie może naruszać podstawowych reguł i specyfiki kanonicznego procesu małżeńskiego, w tym zasady tajności, toteż ewentualne dołączanie odpisów z akt, o czym stanowi pkt 3 $\S 99$ wymienionego Regulaminu, byłoby w tym przypadku niedopuszczalne.

Wniosek o udzielenie pomocy sądowej trybunał kościelny winien kierować do sądu rejonowego, w którego obszarze właściwości dana czynność miałaby być wykonana (o czym wprost stanowi art. 44 $\S 4$ u.s.p.), jednakże nie bezpośrednio, lecz za pośrednictwem Ministra Sprawiedliwości, co jednoznacznie wynika z treści cytowanego wyżej art. $44 \S 3$ u.s.p. Zapis powyższy zdaje się wskazywać, iż jakkolwiek zasadą $\mathrm{w}$ prawie państwowym jest, iż zlecenie przeprowadzenia dowodu wiąże sąd wezwany ${ }^{38}$, to jednakże w przypadku wniosku o pomoc pochodzącego od organu orzekającego innego niż wymienione w art. 44 § 1 i 2 u.s.p. zasadność kierowania takiego wniosku do wykonania sądowi rejonowemu podlega uprzedniej weryfikacji Ministra Sprawiedliwości. Gdyby przyjać, iż Minister Sprawiedliwości przedmiotowy wniosek może jedynie przekazać dalej, czyli musi automatycznie skierować go do sądu rejonowego bez żadnych innych możliwości decyzyjnych w tym względzie, to jego rola sprowadzałaby się wyłącznie do funkcji stricte doręczycielskich, co w oczywisty sposób pozostawałoby w sprzeczności z wykładnią celowościową tej regulacji prawnej. Mając zatem to na uwadze, stwierdzić należy, iż powyższy przepis oznacza, że Minister Sprawiedliwości może wniosek

${ }^{38}$ Zasadę tę jednoznacznie statuuje $\S 101$ pkt 1 wymienionego Regulaminu. 
pochodzący od pozasądowego organu orzekającego przyjąć i skierować do wykonania właściwemu sądowi rejonowemu, może uzależnić przekazanie odezwy od jej uzupełnienia, ale może również prośby o pomoc nie uwzględnić i odezwę zwrócić nadawcy bez wykonania. Jeśli jednakże wnioskowi zostanie nadany dalszy bieg, odezwa ta winna wiązać sąd rejonowy, czyli sąd ten nie mógłby owej odezwy zwrócić, nawet jeśli występowałyby w niej braki, o których mowa we wskazanym wyżej § 99 pkt. 1 u.s.p.

Zatrzymując się przy problematyce dotyczącej pozyskiwania dokumentów medycznych, zaznaczyć należy, iż możliwość posiłkowania się w tym względzie pomocą sądu powszechnego nie oznaczałaby „obejścia” ustawowych reguł dotyczących uchylenia tajemnicy lekarskiej. Dokumenty medyczne wydane na żądanie sądu powszechnego wykonującego rekwizycję sądu kościelnego nie byłyby bowiem udostępniane trybunałowi ad oculos. Przedmiotowy dowód przeprowadzałby sąd powszechny, zaś sąd kościelny, nie mając bezpośredniego wglądu w dokumentację, mógłby ocenić jej walor dowodowy w oparciu o relację sądu powszechnego. W przypadku gdyby informacje zawarte w rzeczonych dokumentach już primo facie wskazywały na ich niewielkie znaczenie dowodowe lub gdyby były one wprawdzie istotne, lecz na tyle lakoniczne, że można byłoby uznać, iż relacja sądu powszechnego $\mathrm{w}$ pełni oddaje ich treść, pomoc sądową na tym etapie można byłoby zakończyć. Bardziej złożona sytuacja powstawałaby, wówczas, gdyby dokumentacja, którą uzyskał sąd powszechny zawierała informacje różnorakie, była obszerna i wysoce specjalistyczna, a zatem gdy należałoby wnioskować, iż zwięzły opis sądu powszechnego mógłby odbyć się ze szkodą dla kompletności informacji zawartych $\mathrm{w}$ tym materiale, a $\mathrm{w}$ dodatku, gdy należałoby przypuszczać, iż w związku z pozyskaniem tych dokumentów w sprawie będzie zachodziła konieczność powołania biegłego. Biegły winien mieć możliwość bezpośredniego dostępu do dowodu, gdyż bazowanie na relacji pośredniej, zwłaszcza w odniesieniu do dokumentów tak specyficznych jak dokumentacja lekarska, z oczywistych względów mogłoby zwiększać ryzyko błędu i wypaczać wnioski końcowe. Skoro jednakże tylko sąd powszechny miałby bezpośredni wgląd w dokumenty, to również tylko biegły powołany przez ten sąd mógłby zapoznać się z tymi dokumentami bezpośrednio. Ani biegli powołani przez trybunał kościelny, ani biegli wydający w sprawie opinie prywatne takiej moż- 
liwości nie mieliby, gdyż w tego rodzaju układzie procesowym nie należeliby do podmiotów, wobec których tajemnica lekarska byłaby uchylona. Aby zatem pogodzić wszystkie powyższe wymogi, wydaje się, iż w omawianej sytuacji sąd powszechny winien poinformować trybunał kościelny o charakterze i rodzaju uzyskanych dokumentów oraz o podstawowych informacjach tam zawartych, umożliwiając w ten sposób trybunałowi podjęcie decyzji co do tego, czy widzi on potrzebę zasięgnięcia opinii biegłego. Jeśli tak - biegłego powoływałby sąd powszechny, jednakże spośród biegłych wskazanych przez trybunał kościelny. Kwestia wskazania biegłego przez sąd kościelny wydaje się istotna o tyle, iż w doktrynie kanonistycznej przyjmuje się, że pożądane jest, aby biegły operował terminologią kanoniczną, tak aby wydana przez niego opinia była przydatna dla procesu kanonicznego, ale nade wszystko wymaga się, by biegły, wydając swoją opinię, uwzględniał zasady antropologii chrześcijańskiej oraz nauczanie Kościoła w materii małżeństwa ${ }^{39}$. Jeśli weźmie się pod uwagę fakt, iż biegli, z którymi współpracują sądy kościelne, nierzadko są również biegłymi z listy prezesów sądów okręgowych, to powyższy postulat nie wydaje się trudny do zrealizowania.

Przeprowadzenie rekwizycji w zakresie pozyskania dokumentów i dopuszczenia dowodu $z$ opinii biegłego w sposób wyżej przedstawiony pozwala $\mathrm{z}$ jednej strony zachować ustawowe wymogi związane z respektowaniem tajemnicy lekarskiej, zachowuje reguły procedury cywilnej, ale również w niczym nie ogranicza władzy sądzenia trybunału kościelnego. To bowiem, czy w konkretnym przypadku będzie zachodziła potrzeba dopuszczenia dowodu z opinii biegłego, podlega ocenie trybunału kościelnego i de facto będzie jego decyzją, zrealizowaną jedynie przez sąd powszechny. Trybunał będzie miał również wpływ na samo powołanie biegłego poprzez imienne jego wskazanie (zgodnie z wymogami kan. $1575 \mathrm{KPK}$ ), a zatem również w tym wymiarze zachowa on pełnię swych kompetencji. Opinię tak uzyskaną należałoby traktować jako opinię ex officio.

W przypadku rekwizycji dotyczącej przesłuchania świadka (strony) celowe byłoby nie tylko precyzyjne wskazanie faktów i okoliczności, w związku z którymi daną osobę należałoby przesłuchać, ale również

${ }^{39}$ G. LeszCZYŃSKI, Wartość dowodowa opinii biegłego $w$ procesie o stwierdzenie nieważności małżeństwa, „Ius Matrimoniale” 2004, t. 9(15), s. 139. 
załączenie listy konkretnych pytań. Trybunał kościelny winien dokładnie podać adres wzywanej osoba a także, w zależności od charakteru sprawy, krótką informację o regułach tajności procesu kanonicznego $\mathrm{z}$ prośbą o jej ewentualne uwzględnienie w trakcie przeprowadzania postulowanej czynności.

Osobnym zagadnieniem jest kwestia kosztów związanych z wykonaniem rekwizycji. Nie ulega bowiem wątpliwości, iż przeprowadzenie dowodu, jak omówione powyżej powołanie biegłego czy też przesłuchanie świadka, który może żądać diety i zwrotu kosztów podróży, wiąże się z wydatkami, które z naturalnych względów winien uiścić ten, kto z prośbą o pomoc występuje. Reguła zawarta w pkt. 4 $\S 99$ Regulaminu wskazuje, że jeżeli wykonanie czynności uzależnione jest od uiszczenia zaliczki, sąd wzywający (czyli ten, który zwraca się z wnioskiem o rekwizycję) winien zażądać jej od strony i przekazać ją sądowi wezwanemu (temu, który rekwizycję będzie wykonywał) równocześnie z pismem o udzielenie pomocy, chyba że względy ekonomii postępowania przemawiają za tym, aby do złożenia zaliczki wezwał stronę bezpośrednio sąd wezwany. Odnosząc tę regułę do rekwizycji z wniosku trybunału kościelnego, zauważyć należy, iż sytuację, w której sąd wezwany miałby żądać zaliczki bezpośrednio od strony procesu kanonicznego, należałoby odrzucić jako nieracjonalną tak z uwagi na wspomnianą zasadę ekonomii procesowej, jak i specyfikę postępowania cywilnego i kanonicznego. Wydaje się, iż nie byłoby również celowe, aby trybunał kościelny dołączał zaliczkę do pisma zawierającego wniosek o rekwizycję, skoro po pierwsze: wniosek ten nie byłby kierowany bezpośrednio do sądu, lecz do Ministra Sprawiedliwości i w momencie „uruchomienia” tej procedury nie byłoby wiadomo, czy dojdzie ona do skutku, po wtóre: nie w każdej sprawie dałoby się z góry przewidzieć, że koszty te powstana, tj. że np. dokumenty zostaną pozyskane i opinia biegłego będzie konieczna. W świetle powyższego stwierdzić należy, iż trybunał winien być obowiązany do uiszczenia zaliczki dopiero wówczas, gdy jego prośba o pomoc zostanie uwzględniona przez Ministra Sprawiedliwości, trafi do sądu rejonowego i gdy ten wezwie do jej zapłacenia, wskazując wysokość żądanej kwoty. Trybunał kościelny zaliczkę winien uzyskać od strony na zasadach, które odnoszą się do regulowania należności w sprawach małżeńskich. 


\section{Zakończenie}

Przedstawiona powyżej analiza zagadnienia rekwizycji pomiędzy sądami kościelnymi i powszechnymi uprawnia do konkluzji, iż tego rodzaju pomoc znajduje swoje uzasadnienie zarówno w regulacjach obu porządków prawnych, których dotyczy, jak również w oczekiwaniach wiernych, będących uczestnikami kanonicznych procesów małżeńskich. W odniesieniu do omawianej instytucji, poza przedstawionymi wyżej procesowymi korzyściami, trudno doszukać się jakichkolwiek przesłanek, które mogłyby wskazywać, iż jej stosowanie w praktyce może powodować negatywne konsekwencje: stanowić nadmierne obciążenie sądownictwa powszechnego, zakłócać funkcjonowanie sądów kościelnych i świeckich bądź też stanowić zagrożenie dla autonomii kościelnego i świeckiego porządku prawnego. Dopuszczenie możliwości istnienia współpracy pomiędzy wymienionymi sądami w przedmiocie rekwizycji nie oznacza przerzucenia na sądownictwo powszechne trudnych czynności dowodowych i w żadnej mierze nie jest też zamachem na procesową odrębność i tożsamość obu tych systemów prawnych. Stwierdzona powyżej dopuszczalność stosowania rekwizycji w omówionym kształcie nie oznacza bowiem - co wyraźnie podkreślić należy - jej powszechności. Rekwizycja sama w sobie, będąc odstępstwem od zasady bezpośredniości, jest w procesie środkiem szczególnym, zaś jeśli zważy się na wyjątkową specyfikę rekwizycji dokonywanej pomiędzy dwoma porządkami prawnymi, jej wyjątkowy, a nawet - rzec by można - ,extraordynaryjny” charakter jest oczywisty. Oczywiste jest również i to, że skoro nadanie biegu konkretnej odezwie sądu kościelnego wymagać będzie każdorazowo weryfikacji i decyzji Ministra Sprawiedliwości, to trudno uznać, by rekwizycja w takim kształcie stała się instytucją masową i by sądy kościelne gremialnie scedowały przesłuchiwanie świadków i stron na sądy powszechne, i by sądy te zajmowały się głównie poszukiwaniem dokumentów dla potrzeb małżeńskich procesów kanonicznych. Trudno też zakładać, by sędziowie kościelni sięgali do tej instytucji bezrefleksyjnie i pochopnie, ,dobrowolnie" ograniczając tym samym możliwości osobistego i bezpośredniego kontaktu z materiałem dowodowym. Nie ulega zatem wątpliwości, iż ewentualne obawy sądownictwa powszechnego co do masowego charakteru omawianej instytucji są bezzasadne. Jeśli przy tym weźmie się pod uwagę fakt, iż wykonywanie 
rekwizycji z wniosków sądów zagranicznych staje się nieomal powszechną praktyką sądów świeckich, ewentualne zastrzeżenia co do pomocy sądowej świadczonej przez te sądy trybunałom kościelnym orzekającym w sprawach wiernych będących obywatelami tego kraju - trudno byłoby racjonalnie uzasadnić.

Reasumując, stwierdzić należy, iż w odniesieniu do omawianej rekwizycji nie ma przeszkód natury prawnej, które uniemożliwiałyby jej stosowanie. Skoro zaś rekwizycja ta daje stronom oraz ich przedstawicielom możliwość pełniejszego dowodzenia swych racji w procesie zaś trybunałowi kościelnemu możliwość odkrycia prawdy, jej procesowa przydatność nie budzi wattpliwości.

\section{Civil-canonical requisition? Legal assistance between the courts of the Church and the public judiciary in Poland}

The article concerns the requisition (mutual aid) between the ecclesial and public courts in Poland. The analysis of existing legislation leads to the conclusion that the ecclesial tribunals can benefit from assistance from Polish public court. This is allowed by the art. $44 \S 3$ of the Act of 27 July 2001 The law of universal regimes. It obliges the public courts to exercise specific judicial acts at the request of the „other adjudicating authorities" if such a request will be directed by the mediation of the Minister of Justice. Taking into consideration that the concordat has enabled the Church to perform its mission free and public as well as exercise of jurisdiction, it must be assumed that „other adjudicating authorities” may be ecclesial tribunals. 